\title{
EFFECT OF WATER AND FEED SALINITY ON COAT COVER TRAITS OF BARKI SHEEP IN SOUTH SINAI
}

\author{
Anous, M. R. E. ${ }^{(1)}$; Abdallah, E. B. ${ }^{(1)}$; Hekal1,Samya, A. ${ }^{(2)}$ \\ and El-Shemy, K. A. A. ${ }^{(2)}$ \\ 1) Animal Production Department, Faculty of Agriculture, Ain Shams \\ University 2) Wool Production and Technology Department, Division of \\ Animal Production, Desert Research Center
}

\begin{abstract}
Twenty nine Barki sheep ewes (2-3 years old) were randomly assigned into four groups (7, 7, 8 and 7 animals for group 1, 2, 3 and 4, respectively) to investigate the impact of salinity in both water and feed on some wool fiber traits (greasy fleece weight; GFW, fibre diameter; FD, staple length; STL, fibre length; FL and fibre type ratios; FTR) and skin follicles characteristics (secondary to primary follicles ratio; S/P ratio) in addition to triiodotyronine; T3 and thyroxin; T4 hormones under semi-arid condition of South Sinai, Governorate, Egypt. Ewes of group 1 (G1) were served as control and fed on berseem hay and drink tap water. Ewes of group 2 (G2) were fed on berseem hay and drink saline water, while ewes of group 3 (G3) and group 4 (G4) were fed on salt-tolerant plants and drink either tap water or saline water, respectively. Results of the present study showed the high variability of both fibre lengths and fibre type ratios compared to the other traits. Type of ration had a significant $(\mathrm{P}<0.05$ to $\mathrm{P}<0.001)$ source of variation for the greasy fleece weight, fibre diameter, staple length and coarse fibre length, while had not significant effect on fibre type ratios, fine fibre and kemp lengths and the secondary to primary follicles ratio ( $\mathrm{S} / \mathrm{P}$ ratio).

Ewes in G1 had higher GFW and S/P ratio, longer coarse fibres (FL) and smaller FD than ewes in the other groups. However, differences among groups were not significant in the case of fibre type ratios, FL (fine fibres) and kemp. Ewes in both G2 and G4 showed the lighter GFW and the shorter SL compared to their partners in the other two groups.

In conclusion, results indicated that Barki sheep are tolerant to both drinking saline water and feeding on salt tolerant plants although there was
\end{abstract}


decreased in greasy fleece weight and staple length with slightly increases in fibre diameter.

Keywords: Saline water, Salt tolerant plants, Wool characteristics, Sheep.

\section{INTRODUCTION}

In desert, the underground water is the main source of water which may contains different degrees of salinity. Ray (1989) reported water salinity to be considered as an important factor in determining the suitability of a particular source for livestock. Most previous local studies concerned the effect of water salinity on the performance and physiological responses of desert animals (Ibrahim, 1995 and El-Sherif and El-Hassanein, 1996), however, few studies took in consideration its effects on coat cover characteristics in sheep (Taha et al., 2009; Abd El-Ghany et al., 2012 and Helal and Fayed, 2013).

On the other hand, the most common existed vegetation along the grazing areas is halophytes and salt tolerant plants that contain different types of anti-nutritional factors and being less palatable. (Helal and Fayed, 2013). This may decrease the utilization of this vegetation by sheep (Ben Salem et al., 2005; Kandil and El-Shaer, 1990).

In Egypt, sheep are reared mainly for meat and secondary for coarse wool production. Wool is used by most of Bedouins communities for making handmade products. Thus, producing good quality wool could improve the Bedouins handmade products which lead to improve their economic value. Wool, as one of sheep products, is influenced by the quantity and quality of both drinking water and type of feeding plants. Therefore, this study was performed to investigate the impact of salinity, in both drinking water and salt 
tolerant plants on some wool fiber traits, skin follicles characteristics (i.e. coat cover) and blood thyroid hormones of the Barki sheep.

\section{MATERIALS AND METHODS}

This research was carried out during the period from July 2011 to January 2012 at South Sinai Research Station situated in Ras Sudr (latitude: 29,6236 N; longitude: 32,7148 E; elevation: 16 m), South Sinai Governorate, belonging to the Desert Research Center (DRC), Ministry of Agriculture and Land Reclamation, Egypt.

Animals and Management: Twenty nine of Barki ewes (2-3 years old) were randomly assigned into four groups (7, 7, 8 and 7 animals for group 1, 2, 3 and 4, respectively) according to both type of drinking water and feed. Group 1 (G1) was served as control and fed on 3/4 $\mathrm{kg}$ berseem hay (Trifolium alexandrinum) per ewe per day and drink tab water; TW (salinity= 247 ppm) ad libidum. Group 2 (G2) was fed the same roughage diet and drink saline water; SW (6000 ppm of TDS) ad libidum, while G3 and G4 were fed on 2.5 $\mathrm{kg}$ salt-tolerant plants (Alfalfa) per ewe per day as a source of roughage and drink either TW or SW, respectively ad libidum.

All experimental groups were offered concentrate feed mixture (3/4 $\mathrm{kg} / \mathrm{head} /$ day) to cover their nutritional requirements of energy according to Kearl (1982). All experimental animals were kept in semi-open pens under the same managerial and hygienic conditions and diagnosed as clinically free from internal and external parasites. 


\section{1- Wool Measurements:}

1-1 Greasy fleece weight (GFW): Greasy fleece weight (GFW, kg) obtained from individual animals immediately after shearing at the end of the experimental period (about 7 months from the beginning). At shearing time, each fleece was divided into two categories; namely skirting and fleece wool as reported by Guirgis (1973). Skirting processes is considered as the beginning of the clip preparation where the lowest grade parts of the fleeces were removed, such as the belly, neck, tail, and colored wool, while the rest of the clip called fleece wool. The weight $(\mathrm{kg})$ of each category was recorded, then, fleece wool was kept in plastic bags for further analysis.

Wool samples were taken at the end of the experimental period from 10 $\mathrm{cm} 2$ patch of left clipped mid-side position of each animal as close as possible to the skin surface. Then, the following measurements were recorded.

1-2- Fibre diameter (FD): Short sections of at least 300 fibres were prepared from each sample and counted on glass slides immersed in paraffin oil and covered with glass covers. Fibre diameter was measured in microns, directly after mounting by a computerized Image analyzer (LEICAQ $500 \mathrm{MC}$ ) with lens 4/0.12, then the average fibre diameter was calculated.

1-3- Staple length (STL): Staple length of wool was measured in $\mathrm{cm}$ and recorded for 10 staples, taking randomly from each wool sample, using a ruler fixed on a black velvet board to the nearest $0.5 \mathrm{~cm}$ (Chapman, 1960). The length measurement was taken from the base of the staple to the dense part of the tip without stretching the staple. 
1-4- Fibre length (FL): Ten fibers were taken at random from each sample to measure their length using a millimeter ruler fixed on a black velvet board. Just enough tension was applied to straighten the fiber without stretching. The fibre length was taken as the distance between the base and the tip of the fiber.

1-5- Fibre type ratio (FTR): Representative samples were taken from the different classes of the wool fibres. Sub-samples were separated from each sample, placed on a black velvet board and split into the different fibre types, i.e. fine (non- medullated), coarse (medullated), hetero and kemp (more than $85 \%$ of cross sectional area as medulla). Fibre type ratio was then calculated in percentage by dividing the number of each fibre type by the total number of fibres present in each sample (Guirgis, 1967).

2- Histological structure of the skin: The skin specimens were taken from the left mid-side position of each animal, over the last rib, by means of a curved scissors in enough depth to represent the epidermis and dermis, then fixed on a foam to get flattened. The samples were fixed in calcium formol for about 24 hours (Barker, 1958), washed and left for 24 hours in distilled water then transferred to $70 \%$ ethanol. Specimens were then dehydrated in an ascending series of ethanol (30 minutes in each 70\%, $80 \%$ and $90 \%$ ethanol and finally two changes each for 15 minutes absolute ethanol).

The specimen were cleared in benzene for about 30 minutes, infiltrated in paraffin wax of a melting point of $60{ }^{\circ} \mathrm{C}$ ( 4 changes, 20 minutes each) and then embedded in the same paraffin to prepare the blocks. Transverse sections (6-8 microns in thickness) were prepared for histological studies. 
For general histological observations of the wool follicles; the sections were stained by Haematoxylin and Eosin stain (Drury and Wallington, 1980). The follicle groups were counted and the secondary $(\mathrm{S})$ to primary $(\mathrm{P})$ follicles ratio ( $\mathrm{S} / \mathrm{P}$ ratio) was estimated. The $\mathrm{S} / \mathrm{P}$ ratio was calculated in ten follicles groups for each skin samples of the experimental animals. Histological features were conducted in the Central Lab of DRC.

3- Blood hormones: Blood samples were taken monthly from all experimental groups, before feeding and drinking, through vein puncture (using clinical needle) and withdrawn into sterile tubes containing EDTA as anticoagulant.

The thyroid hormones (triiodothyronine, T3 and thyroxine, T4) were quantified by ELISA method using IMMUNOSPEC kits supplied by Immunospec Corporation, 7018 Owensmounth Ave. Suite 103 Canoga Park, CA 91303, USA.

\section{STATISTICAL ANALYSIS}

Data were analyzed using the general linear model (GLM) procedures of the Statistical Analysis System (SAS, 2004) and the following model was conducted:

$$
Y \mathbf{i j}=\mu+\mathbf{F i}+\mathbf{e i j}
$$

Where:

Yij = any observation (wool and skin parameters) in the ith type of feeding;

$\mu=$ overall mean;

$\mathrm{Fi}=$ effect of the $i$ th type of feeding $(\mathrm{i}=1, \ldots, 4 ; 1=$ animals fed on berseem hay and drink tap water, $2=$ animals fed on berseem hay and drink saline 
water, $3=$ animals fed on salt-tolerant plants and drink tap water and $4=$ animals fed on salt-tolerant plants and drink saline water);

eij $=$ random residual error .

Differences among means were tested by Duncan Multiple Range test (Steal and Torrie, 1980).

\section{RESULTS AND DISCUSSION}

Overall means and variability of coat cover traits of Barki sheep ewes and also the $\mathrm{F}$ values of the analysis of variance are presented in Table (1). The mean value for greasy fleece weight; GFW in Barki ewes was $1.56 \mathrm{~kg}$. In the same breed, higher values for greasy fleece weight; GFW (2.42 and 3.1 kg) were reported by Seoudy (1966) and Fahmy (1967), respectively, compared to the present results. However, Azzam (1999) and Gad Allah (2001) obtained values of $1.73 \mathrm{~kg}$ and $2.53 \mathrm{~kg}$, respectively.

The mean value for fibre diameter; FD, staple length; STL and secondary to primary follicles ratio, $\mathrm{S} / \mathrm{P}$ ratio in Barki ewes was $27.11 \mu \mathrm{m}, 10.07 \mathrm{~cm}$ and 3.25, respectively. Higher values, ranged between 30.97 and $33.80 \mu \mathrm{m}$, were also reported for FD by Azzam (1982), Gad Allah (2001) and Al-Betar (2007) and confirmed by the results reported for STL and S/P ratio by Al-Betar (2000), Gad Allah (2007) and Taha (2004).

The mean value for the length of fine, coarse and kemp fibres; FL, in Barki ewes was 63.44, 24.67 and $4.43 \mathrm{~cm}$, respectively. However, the mean values for fibre type ratios, FTR were $63.45,24.67,7.45$ and $4.43 \%$ for fine, coarse, hetero and kemp fibres, respectively. Guirgis (1973) found that fibre type percentages in Barki wool were 69.11, 26.03, 0.44 and $4.42 \%$ for fine, 
coarse, heterotype and kemp fibres, respectively. Gad Allah (2007) found that fibre type percentages of Barki wool were 68.47, 22.31, 2.28 and $6.94 \%$ for fine, coarse, heterotype and kemp fibres, respectively.

In general, the increase in wool production is a result of increasing both fiber diameter and staple length.

Table (1): Number of observed samples (N), overall means, standard deviations $(\mathrm{SD})$, coefficients of variation $(\mathrm{CV} \%)$ and $\mathrm{F}$ values of the analysis of variance for coat cover traits of Barki sheep ewes.

\begin{tabular}{|c|c|c|c|c|c|}
\hline Items & N & Mean & SD & CV\% & F value \\
\hline \hline GFW $(\mathrm{kg})$ & 29 animals & 1.56 & 0.40 & 26.00 & $5.04^{* *}$ \\
\hline FD $(\mu \mathrm{m})$ & 67 & 27.11 & 4.21 & 16.00 & $3.47^{*}$ \\
\hline STL $(\mathrm{cm})$ & 156 & 10.07 & 1.81 & 18.00 & $15.97^{* * *}$ \\
\hline FL $(\mathrm{cm})$ & & & & & \\
Fine & 114 & 63.44 & 8.73 & 14.00 & $0.60 \mathrm{~ns}$ \\
Coarse & 119 & 24.67 & 7.61 & 31.00 & $4.19^{* *}$ \\
Kemp & 114 & 4.43 & 3.30 & 74.00 & $1.16 \mathrm{~ns}$ \\
\hline FTR & & & & & \\
Fine (\%) & & 63.45 & 8.73 & 14.00 & $1.26 \mathrm{~ns}$ \\
Coarse (\%) & 66 & 24.67 & 7.61 & 31.00 & $0.68 \mathrm{~ns}$ \\
Hetero (\%) & & 7.45 & 5.73 & 77.00 & $0.57 \mathrm{~ns}$ \\
Kemp (\%) & & 4.43 & 3.30 & 74.00 & $0.85 \mathrm{~ns}$ \\
\hline S/P ratio & 67 & 3.25 & 0.79 & 24.00 & $2.02 \mathrm{~ns}$ \\
\hline \hline
\end{tabular}

$\mathrm{GFW}=$ Greasy fleece weight; $\mathrm{FD}=$ Fibre diameter; $\mathrm{STL}=$ Staple length; $\mathrm{FL}=$ Fibre length; FTR= Fibre type ratio; $\mathrm{S} / \mathrm{P}$ ratio= secondary to primary follicles ratio. $\mathrm{ns}=\mathrm{P}>0.05 ; *=\mathrm{P}<0.05 ; * *=\mathrm{P}<0.01 ; * * *=\mathrm{P}<0.001$.

The variability of body coat cover traits expressed by the values of CV\% (Table 1) showed the high variability of both fibre type lengths and fibre type ratios compared to the other traits which reflects, in general, the effect of 
saline water intake and feeding salt tolerant plants on coat cover traits in this population of sheep, especially on fibre types (lengths and percentages).

F values for body coat cover traits of Barki sheep ewes (Table 1) showed that type of feeding was highly significant $(\mathrm{P}<0.01$ or $\mathrm{P}<0.001)$ or significant $(\mathrm{P}<0.05)$ source of variation for greasy fleece weight, fibre diameter, staple length and coarse fibre length, while it was not significant (P $>0.05)$ for the fibre type ratios, fine fibre and kemp lengths and the secondary to primary follicles ratio.

The significant variance among the types of feeding indicates some small diversity among experimental groups for GFW, FD and STL. The other variables which express the quality of wool (i.e. FL, FTR and S/P ratio) were not affected by the type of feeding. There was general agreement between our results and the previous results reported on the same breed by Abd El-Ghany et al. (2012).

Least squares means $( \pm \mathrm{SE})$ for body coat cover traits of Barki ewes are presented in Table 2. Ewes of G1 (fed on berseem hay and drink tap water) had higher greasy fleece weight and S/P ratio, longer coarse fibres and smaller fibre diameter than ewes of the other groups. They also showed intermediate staple length, however the differences among groups are small and not significant $(\mathrm{P}<0.05)$. Ewes of both $\mathrm{G} 2$ (fed on berseem hay and drink saline water) and G4 (fed on salt-tolerant plants and drink saline water) showed the lighter greasy fleece weight and the shorter staple length compared to the ewes of the other two groups, however, they had intermediate values of both fibre diameter and S/P ratio. Ewes of G3 (fed on 
salt-tolerant plants and drink tap water) scored the highest fibre diameter, staple length and the smallest S/P ratio values.

The increase of the saline water and salt tolerant plants intake by the Barki ewes decreased the greasy fleece weight and the staple length, while it increased slightly the fibre diameter. However, it did not affect the percentage of fibre types. These results indicate that Barki sheep are tolerant to both drinking saline water and feeding salt tolerant plants.

Table (2): Least squares means $( \pm$ SE) showing the effect of type of feeding on coat cover traits of ewes Barki sheepT

\begin{tabular}{||l|c|c|c|c|}
\hline \multirow{2}{*}{\multicolumn{1}{|c|}{ Items }} & \multicolumn{4}{c|}{ Experimental groups } \\
\cline { 2 - 5 } & G1 & G2 & G3 & G4 \\
\hline \hline GFW $(\mathrm{kg})$ & $2.06 \pm 0.15 \mathrm{a}$ & $1.32 \pm 0.15 \mathrm{~b}$ & $1.52 \pm 0.14 \mathrm{~b}$ & $1.35 \pm 0.15 \mathrm{~b}$ \\
\hline FD $(\mu \mathrm{m})$ & $24.60 \pm 1.09 \mathrm{~b}$ & $26.69 \pm 0.94 \mathrm{ab}$ & $29.31 \pm 1.02 \mathrm{a}$ & $27.67 \pm 1.09 \mathrm{ab}$ \\
\hline STL $(\mathrm{cm})$ & $10.54 \pm 0.30 \mathrm{~b}$ & $9.71 \pm 0.29 \mathrm{c}$ & $11.77 \pm 0.33 \mathrm{a}$ & $8.99 \pm 0.26 \mathrm{c}$ \\
\hline FL: & $12.00 \pm 0.60 \mathrm{a}$ & $11.93 \pm 0.57 \mathrm{a}$ & $11.57 \pm 0.58 \mathrm{a}$ & $12.66 \pm 0.59 \mathrm{a}$ \\
Fine $(\mathrm{cm})$ & $16.07 \pm 0.72 \mathrm{a}$ & $12.87 \pm 0.72 \mathrm{~b}$ & $13.08 \pm 0.72 \mathrm{~b}$ & $13.52 \pm 0.73 \mathrm{~b}$ \\
Coarse $(\mathrm{cm})$ & $4.60 \pm 0.39 \mathrm{a}$ & $4.31 \pm 0.39 \mathrm{a}$ & $0.98 \pm 0.39 \mathrm{a}$ & $4.98 \pm 0.39 \mathrm{a}$ \\
Kemp $(\mathrm{cm})$ & & & & \\
\hline FTR: & & & & \\
Fine $(\%)$ & $64.55 \pm 2.25 \mathrm{a}$ & $63.70 \pm 1.95 \mathrm{a}$ & $59.98 \pm 2.18 \mathrm{a}$ & $65.69 \pm 2.25 \mathrm{a}$ \\
Coarse $(\%)$ & $24.51 \pm 1.96 \mathrm{a}$ & $23.96 \pm 1.70 \mathrm{a}$ & $26.93 \pm 1.90 \mathrm{a}$ & $23.38 \pm 1.97 \mathrm{a}$ \\
Hetero $(\%)$ & $7.03 \pm 1.48 \mathrm{a}$ & $6.94 \pm 1.28 \mathrm{a}$ & $9.07 \pm 1.43 \mathrm{a}$ & $6.81 \pm 1.48 \mathrm{a}$ \\
Kemp $(\%)$ & $3.90 \pm 0.85 \mathrm{a}$ & $5.41 \pm 0.74 \mathrm{a}$ & $4.02 \pm 0.82 \mathrm{a}$ & $4.11 \pm 0.85 \mathrm{a}$ \\
\hline \multicolumn{1}{|c|}{ S/P ratio } & $3.59 \pm 0.20 \mathrm{a}$ & $3.30 \pm 0.18 \mathrm{ab}$ & $2.90 \pm 0.19 \mathrm{~b}$ & $3.22 \pm 0.20 \mathrm{ab}$ \\
\hline
\end{tabular}

T: All the tabulated least squares mean values are significant at $\mathrm{P}<0.001$.

$\mathrm{GFW}=$ Greasy fleece weight; FD $=$ Fibre diameter; $\mathrm{STL}=$ Staple length; $\mathrm{FL}=$ Fibre length; FTR= Fibre type ratio; $\mathrm{S} / \mathrm{P}$ ratio= The secondary $(\mathrm{S})$ to primary $(\mathrm{P})$ follicles ratio.

Means with the same letter are not significantly different $(\mathrm{P}>0.05)$.

$\mathrm{G} 1=$ fed on berseem hay and drink tap water, G2= fed on berseem hay and drink saline water, G3= fed on salt-tolerant plants and drink tap water and G4= fed on salttolerant plants and drink saline water. 
Pearce et al. (2002) reported that sheep fed saltbush grew more wool with a higher fibre diameter than control sheep. Hemsley et al. (1975) showed that high salt intakes increase digesta flow, decrease protein degradation in the rumen and increase wool growth. Abd El-Ghany et al. (2012) concluded that feeding on salt tolerant plants (Kochia indica and Pennisetum americanum) mixed with molasses may cause an increase in fiber amino acids contents specially Cysteine, Alanine, Glutamic acid, Proline and Metionine which in turn make changes in physical characteristics of wool fibers; an increase in fiber length and cotting score, and a decrease in fiber cross sectional area and crimp frequency of Barki lambs.

Blood Hormones: Concentration of T3 decrease significantly $(p<0.05)$ among different groups; G1 showed the highest concentration and G3 showed the smallest one. Table (3) showing a slightly decrease in T3 with increasing of salinity. Groups 3 and 4 had remarked decrease concentrations of both T3 and T4. Also, G1 had higher value of T3 compared to G2, however, G2 showed a higher value of T4 more than G1. Metwally (2001) remarked that in camel, SW treatment decreased bothT3 and T4, attributed that to the decrease of feed intake, so that metabolism process decreased. It has been shown that thyroid hormones are important modulators of developmental processes and general metabolism. The relationship between thyroid hormone concentrations and feed intake are very complicated. Several research studies have shown that the lower concentrations of thyroid hormones are not a primary consequence of a lower food intake, resulting mainly from complex neuro-endocrine processes related to the sequential interactions among thermosensors, hypothalamus, adenohypophysis and thyroid (Silanikove, 
2000). Even so, the decreases in the blood tri-iodothyronine and thyroxine concentrations reinforce the tendency for a depressed feed intake (Riis and Madsen, 1985). These results, partially, explain the increase of Fibre diameter, medullated fibre $\%$ and kemp fibre $\%$ in SW groups. Abd El-Ghany and Azzam (2003) observed that the mean values of plasma T3 and T4 tended to decrease with the increase in wool length. Fibre diameter, medullated fibre $\%$ and kemp fibre \% were found to be negatively correlated with $\mathrm{T} 4$ and positively correlated with T3. Kelly et al. (1993) found that wool from sheep (New Zealand Romney rams) that were infused with low levels of thyroxine T4 had greater fibre length, growth rate and fibre diameter than the control group. The authors reported that thyroxine $\mathrm{T} 4$ reduced the size of follicle bulbs.

Table (3): Least squares means $( \pm \mathrm{SE})$ showing the effect of feeding and water salinity on thyroxin $(\mathrm{T} 4, \mu \mathrm{g} / \mathrm{ml})$ and tri-iodothyronine $(\mathrm{T} 3$, $\mathrm{ng} / \mathrm{ml}$ ) concentration of Barki ewe's blood

\begin{tabular}{|c|c|c|c|c|}
\hline Items & G1 & G2 & G3 & G4 \\
\hline \hline T3 & $6.00 \pm 0.097 \mathrm{a}$ & $4.12 \pm 0.097 \mathrm{~b}$ & $1.50 \pm 0.097 \mathrm{~d}$ & $1.94 \pm 0.097 \mathrm{c}$ \\
\hline T4 & $12.09 \pm 1.177 \mathrm{~b}$ & $18.84 \pm 1.177 \mathrm{a}$ & $6.63 \pm 1.177 \mathrm{c}$ & $8.55 \pm 1.177 \mathrm{bc}$ \\
\hline
\end{tabular}

Means with different letters are significantly different $(\mathrm{P}<0.05)$.

$\mathrm{G} 1=$ fed on berseem hay and drink tap water, G2= fed on berseem hay and drink saline water, G3 = fed on salt-tolerant plants and drink tap water and G4= fed on salttolerant plants and drink saline water.

\section{CONCLUSION}

The present study concluded that drinking saline water and feeding salt tolerant plants (Alfalfa) decrease greasy fleece weight and staple length and 
slightly the secondary to primary follicles ratio, while it increased slightly the fibre diameter. Further studies are required to determine if Barki sheep can tolerate water salinity levels for more than $6000 \mathrm{ppm}$ TDS, which is actually the upper limit of salinity tolerance in the present study.

\section{REFERENCES}

Abd El-Ghany, W. H. and Azzam, A. H. (2003): Study of some coat characteristics of sheep and goats exposed to thermal stress in terms of some physiological parameters as response to water deprivation.First Egyptian Syrian Conference. Fac. of Agric. Minia Univ. Egypt. pp.134-141.

Abd El-Ghany, W. H., Younis, F. E., Ramadan, W. A. M., Ibrahim, N. H. and El Shaer, H. M. (2012): Effect of feeding on salt tolerant plants on physical and chemical properties of coat fibers in sheep. J. Animal and Poultry Prod., Mansoura Univ., 3 (11): 511 - 522.

Al-Betar, E.M. (2000): Studies on productive performance and wool traits of Egyptian sheep. M.Sc. Thesis, Faculty of Agriculture, Alexandria University, Alexandria, Egypt, 1 - 174 pp.

Al-Betar, E.M. (2007): Suitability of wool produced from Egyptian sheep for some industrial applications. Ph.D. Thesis, Fac. Agric., Ain Shams Univ., Cairo, Egypt.

Azzam, A.H. (1982): Correlations between some physical wool characteristics of weaning samples and those of the adult fleece of desert Barki sheep . M.Sc. Thesis, Fac. Agric., Ain Shams Univ., Cairo, Egypt.

Azzam, A.H. (1999): Study of some subjective and objective coarse wool traits in Barki sheep. Ph. D. Thesis, Fac. Agric., Zagazig Univ., Banha Branch, Egypt.

Barker, J. R. (1958): Principles of Biological Technique. John Wiley, Bancroft. J. D., New York, USA.

Ben Salem, H., Sourour Abidi, H.P.S. Makkar and Nefzaoui, A. (2005): Wood ash treatment, a cost effective way to deactivate tannins in 
Acacia Cyanophylla. Lindl foliage and to improve digestion by Barbarine Sheep. Animal Feed Science and Technology, 122; 93 108.

Chapman, R.E. (1960): In "Biology of the fleece". (Edited. by Fraser, A.S. and B.F. Short), Animal Research Laboratories. Technical Paper No. 3, CSIRO, Sydney, Australia.

Drury, R. A. E. and Wallington, E. A. (1980): Carleton's histological technique. 4th Ed. Oxford Univ. Press.

El-Sherif, M.M.A., El-Hassanein, E.E. (1996): Influence of drinking saline water on growth and distribution of body fluids in sheep. Alex. J. Agric. Res. 41 (3), 1-9.

Fahmy, M.H. (1967): Genetic and environmental factors affecting sheep production under desert condition. Ph.D. Thesis, Fac. Agric., Ain Shams Univ., Cairo, Egypt.

Gad Allah, A.E. (2001): Studies on some characteristics, clip preparation and the use of Barki wool in the local textile industry. M. Sc. thesis, Faculty of Agriculture, University of Alexandria, Alexandria, Egypt.

Gad Allah, A.E. (2007): Some factors affecting fleece characteristics of Barki sheep. Ph. D. thesis, Faculty of Agriculture, Menoufia University,Egypt.

Guirgis, R.A. (1967): Fibre-type arrays and kemp succession in sheep. J. Agric. Sci. Camb., 68: 75-85.

Guirgis, R.A. (1973): Staple length and kemp as a basis of grading Barki wool . Alex. J. Agric. Res., 21: 235 - 240.

Helal, A. and Fayed, Afaf M.(2013): Wool characteristics of sheep fed on halophyte plants ensiled by some biological treatments. Egyptian Journal of Sheep and Goat Sciences, Vol. 8 (1), P: 131-139-, 2013 (Proceedings Book of 4th International Scientific Conference on Small Ruminant Development) (3-7 Sept., 2012, Sharm El Shiekh). 
Hemsley, J.A., Hogan, J.P. and Weston, R.H. (1975): Effect of high intake of sodium chloride on the utilization of a protein concentrate by sheep. Australian Journal of Agricultural Research, 26: 715-727.

Ibrahim, S.M.N. (1995): Clinic-pathological studies in goats drinking salty water under desert conditions. M.Sc. Thesis. Faculty of Veterinary Sciences, Cairo University, Egypt.

Kandil, H.M. and El-Shaer, H.M. (1990): Comparison between goats and sheep in utilization of high fibrous shrubs with energy feed. Proc. Int. Goat Prod. Symp. Oct. 22-26, 1990 Tallohassee, Florida, U. S. A., 75-79.

Kearl, L. (1982): Nutrient Requirements of Ruminant in Developing Countries. Utah State Univ, Logam, USA.

Kelly, K. E., Haris, P. M., Birtles, M. J., Dellow, D. W. and Hall, A. J. (1993). Cell proliferation in the wool follicles of fleece weight selected and control Romney rams. Aust. J. Agric. Res., 44(2): $239-253$.

Metwally, N. H. (2001): Studies on some physiological and behavioral aspects in camels. M. Sc. Thesis, Fac. of Agric., Minufiya University, Egypt.

Pearce, K.L., Masters, D.G., Friend, C., Rintoul, A. and Pethick, D. W. (2002): Wool growth and liveweight gain in sheep fed a Saltbush and Barley Ration. Anim. Prod. Aust., 24: 337.

Ray, D.E. (1989): Interrelation among water quality, climate and diet on feedlot performance of steer calves. J. Anim. Sci. 67, 357-361.

Riis, P.M. and Madsen, A. (1985): Thyroxine concentration and secretion rates in relation to pregnancy, lactation and energy balance in goats Journal of Endocrinology 107, 421-427.

SAS (2004): Statistical Analysis System Institute, SAS User's Guide, Statistics, 5th Edition, SAS Institute Inc., Cary, NC.

Steal, R. G. D. and Torrie, J. H. (1980): Principals and procedures of statistics. A Biometrical Approach. Second Edition. Mac GrawHill Com. 
Seoudy, A.M. (1966): Effect of crossing Merino and Barki sheep on some wool characteristics. M.Sc. Thesis, Fac. Agric., Ain shams Univ., Cairo, Egypt.

Silanikove, N. (2000): Effect of heat stress on the welfare of extensively managed domestic ruminants. Livest. Prod. Sci., 67: 1-18.

Taha, E. A. (2004): Seasonal effect of some physiological traits and wool characteristics in Barki sheep raised under desert conditions. Ph.D. Thesis, Fac. Agric., Alex. Univ., Alexandria, Egypt.

Taha, E. A., Hekal, S. A. and Helal, A. (2009): Some wool and skin characteristics of Barki sheep fed on some halophytes under desert conditions. J. Agric. Sci. Mansoura Univ., 34 (1): 151-166.

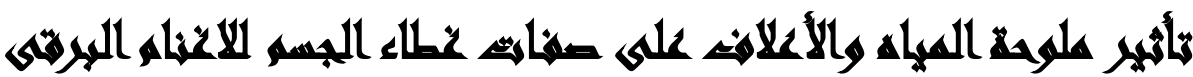

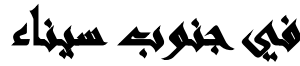

$[r]$

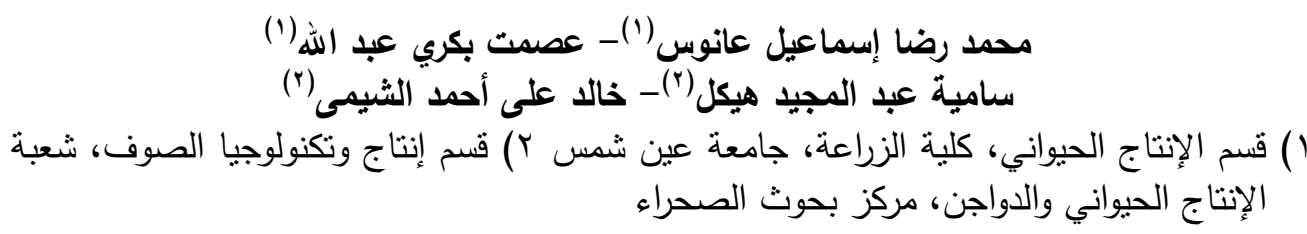

(ll

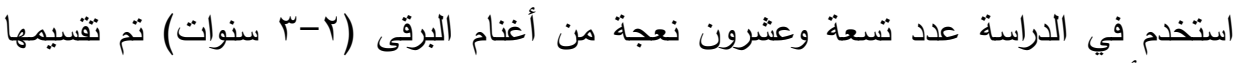

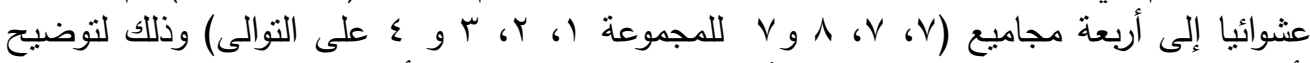

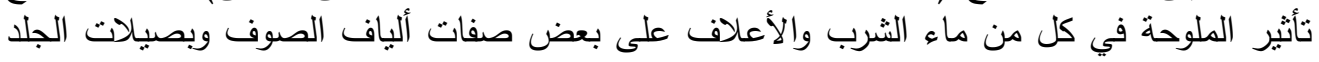

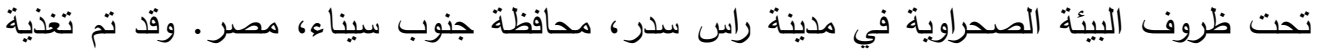

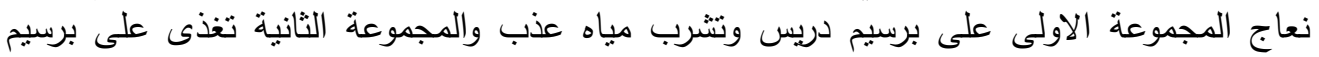

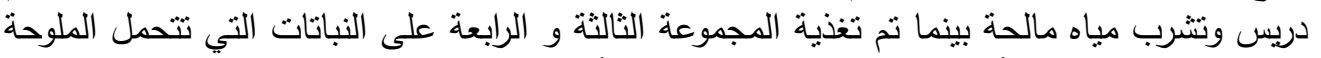
وتترب إما مياه عذب أو مياه مالحة، على التوالي، وأيضا على هرمونات الدية الدماتية تراي ايودوثيرونين

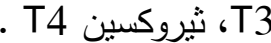


وأظهرت نتائج الدراسة الحالية التباين العالي لكل من أطوال نوع الألياف ونسب الألياف مقارنة

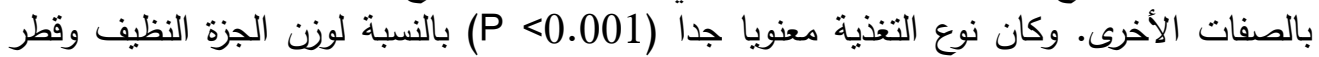

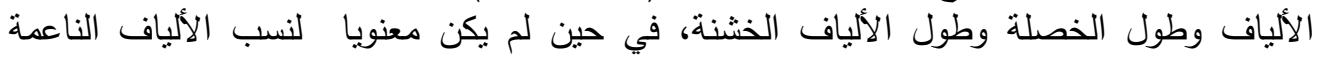
والخشنة ونسبة بصيلات الثانوية إلى الاولية.

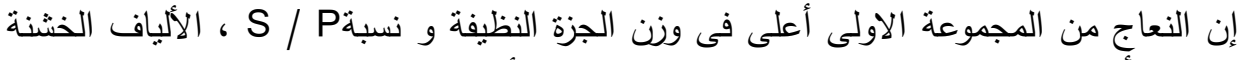

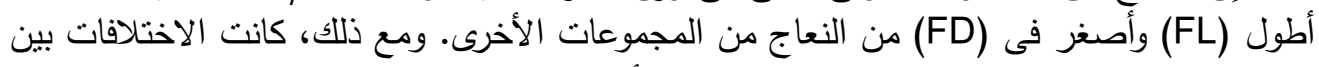

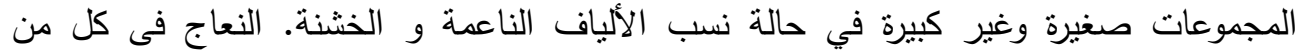
المجموعة الثاتتية والرابعة أظهرت وزن جزة فيرة أخف وزنا وطول خصلة أقصر مقارنة مع المجموعتين

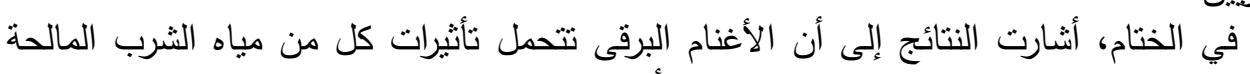
الأخريين.

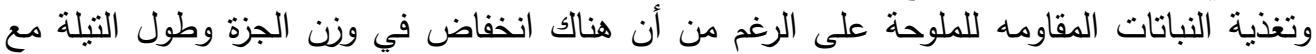
زيادة طفيفة في قطر الألياف. 